\title{
Occurrence, Distribution, and Relative Incidence of Five Viruses Infecting Cucurbits in the State of São Paulo, Brazil
}

\author{
V. A. Yuki, Centro de Fitossanidade, Instituto Agronômico, 13020-902 Campinas, SP, Brazil; J. A. M. Rezende \\ and E. W. Kitajima, Dept. de Fitopatologia, ESALQ/USP, 13418-900 Piracicaba, SP, Brazil; P. A. V. Barroso and \\ H. Kuniyuki, Centro de Fitossanidade, Instituto Agronômico, 13020-902 Campinas, SP; G. A. Groppo, DEX- \\ TRU/CATI, 13073-001 Campinas, SP, Brazil; and M. A. Pavan, Dept. de Defesa Fitossanitária, FCA/UNESP, \\ 18603-970 Botucatu, SP, Brazil
}

\begin{abstract}
Yuki, V. A., Rezende, J. A. M., Kitajima, E. W., Barroso, P. A. V., Kuniyuki, H., Groppo, G. A., and Pavan, M. A. 2000. Occurrence, distribution, and relative incidence of five viruses infecting cucurbits in the state of São Paulo, Brazil. Plant Dis. 84:516-520.

Cucurbits species grown in 38 of 40 agricultural regions in the state of São Paulo, Brazil, were surveyed for the relative incidence of Cucumber mosaic virus (CMV), Papaya ringspot virustype W (PRSV-W), Watermelon mosaic virus-2 (WMV-2), Zucchini lethal chlorosis virus (ZLCV), and Zucchini yellow mosaic virus (ZYMV) during May 1997 and June 1999. Samples from 621 plants, representing eight cultivated species, six wild species, and one commercial hybrid (Cucurbita moschata $\times$ C. maxima), were analyzed by plate trapped antigen enzymelinked immunosorbent assay (PTA-ELISA). PRSV-W and ZYMV were the most frequently found viruses, accounting for 49.1 and $24.8 \%$, respectively, of 605 samples tested. ZLCV, CMV, and WMV-2 were detected in 7.8, 6.0, and $4.5 \%$ of 612,497 , and 423 samples tested, respectively. Double infection was found in 97 samples, and triple infection was found in 10 samples. Quadruple infection was detected in one C. pepo sample. Plants that were symptomatic but negative by PTA-ELISA might be due to abiotic agents, infection by virus for which antiserum was not available, such as Squash mosaic virus, or infection with an as yet uncharacterized virus.
\end{abstract}

Commercial production of zucchini squash (Cucurbita pepo), winter squash ( $C$. maxima and $C$. moschata), hybrid squash (C. maxima $\times$ C. moschata), cucumber (Cucumis sativus), watermelon (Citrullus lanatus), chayote (Sechium edule) and sponge gourd (Luffa acutangula) are produced by several small to medium size growers throughout the state of São Paulo, Brazil. Cucurbit crops occupied approximately 22,130 ha in the state in 1998 , with an estimated production of 579,405 $\mathrm{t}$ (2). Due to the tropical and subtropical weather predominant in São Paulo, most of the species can be grown throughout the year. In addition, wild Cucurbitaceae species such as bitter melon (Momordica charantia), West Indian gherkin (Cucumis anguria), calabash gourd (Lagenaria siceraria), and others can be found naturally almost everywhere at any time.

Cucurbit virus diseases are a worldwide problem, and in the state of São Paulo they represent one of the most limiting factors for growers. Of about 20 different viruses

Corresponding author: J. A. M. Rezende

E-mail: jamrezen@carpa.ciagri.usp.br

Accepted for publication 22 December 1999.

Publication no. D-2000-0316-01R

(C) 2000 The American Phytopathological Society reported on the Cucurbitaceae worldwide (35), eight have been reported in Brazil $(1,4,5,10,15,24,28,32)$. Among these, $\mathrm{Cu}$ cumber mosaic virus (CMV), Papaya ringspot virus-type W (PRSV-W), Squash mosaic virus (SqMV), Watermelon mosaic virus-2 (WMV-2), Zucchini yellow mosaic virus (ZYMV), and Zucchini lethal chlorosis virus (ZLCV) have been found in the state of São Paulo (4,5,24,28,32). Although there are no studies regarding the distribution and relative incidence of these viruses in cucurbit crops, past observation in the states of São Paulo (5), Pará (1), Rio Grande do Norte (12), Mato Grosso (unpublished), Minas Gerais (22), Ceará (14), and in the Distrito Federal (7) indicated that PRSV-W was predominant. A recent survey on viruses infecting melon and watermelon crops in the northeast states of Bahia and Pernambuco showed that WMV-2 and PRSV-W were the most prevalent, with incidence of 68.7 and $31.2 \%$, respectively (6). PRSV-W is still regarded as one of the most destructive pathogens infecting cucurbits in several states of Brazil, even though estimates of crop loss are not available.

Despite the importance of cucurbit crops in São Paulo, only limited local information is available about the incidence of viral diseases and their effect on the yield. For this reason, a 2-year survey was carried out to estimate the incidence of CMV,
PRSV-W, WMV-2, ZLCV, and ZYMV on cultivated and some wild species of Cucurbitaceae. These are the only viruses that have been reported affecting cucurbit crops in the state until now.

\section{MATERIALS AND METHODS}

Survey. Samples were collected during May 1997 and June 1999 from 38 of 40 agricultural regions of the state of São Paulo (Fig. 1). In each region, cucurbit fields and wild cucurbit species were arbitrarily inspected and selected for virus infection. Surveys were preferably conducted during a mid-developmental stage of the plant. Plants were randomly evaluated based on symptoms thought to be caused by virus infection such as chlorosis, veinclearing, mottle and/or leaf malformation, and fruits that were smaller and malformed and showed abnormal discoloration on their surface. Young leaves from some symptomatic plants were placed in plastic bags and examined at IAC, Campinas, ESALQ/USP, Piracicaba, and FCA/UNESP, Botucatu for serological identification of infecting viruses.

Virus identification. The presence of CMV, PRSV-W, WMV-2, ZLCV, and ZYMV was determined using the plate trapped antigen (PTA)-ELISA (18), with some modification. Briefly, test samples diluted 1:20 in $0.05 \mathrm{M}$ carbonate buffer, $\mathrm{pH}$ 9.6, were added to wells of ELISA plate and incubated for $1.5 \mathrm{~h}$ at $37^{\circ} \mathrm{C}$. Polyclonal antiserum diluted $1: 1,000$ in 0.2 $\mathrm{M}$ Tris- $\mathrm{HCl}$ buffer, $\mathrm{pH} 7.2$, was incubated in the wells for $1.5 \mathrm{~h}$ at $37^{\circ} \mathrm{C}$. Goat-antirabbit IgG conjugated to alkaline phosphatase (Sigma A-3687), diluted 1:32,000 in Tris-HCl buffer, was added to the plate and incubated as before. Enzyme substrate, p-nitrophenyl phosphate (Sigma N-9389), was added in $10 \%$ diethanolamine at $\mathrm{pH}$ 9.8. Antiserum against CMV was provided by P. S. T. Brioso (UFRRJ, Rio de Janeiro). Antisera against PRSV-W and ZYMV were produced at ESALQ/USP, Piracicaba, and those against WMV-2 and the nucleocapsid protein of ZLCV were kindly provided by A. C. de Ávila (CNPH/EMBRAPA, Brasília, DF). Virus positive and negative controls were included in all tests. PTA-ELISA reactions were recorded by an $\Sigma 960$ ELISA reader (Metertech, Taiwan) at $A_{405 \mathrm{~nm}}$. A sample 
was considered virus positive if the $A_{405 \mathrm{~nm}}$ value was greater than three times that of healthy plant extract.

\section{RESULTS AND DISCUSSION}

The results of these surveys are summarized in Table 1 and Figure 1. Symptoms due to virus infection and those caused by abiotic agents (insecticide, herbicide, nutritional deficiency, and insect toxemia) were observed in several fields. Incidence of symptomatic plants varied largely, not only among regions but also among cultivated species of cucurbits (data not shown). Of the five viruses tested, PRSV$\mathrm{W}$ and ZYMV were found in 100 and $82 \%$ of the regions, respectively. ZLCV, a new species of Tospovirus (25), was detected in $58 \%$ of the regions, whereas CMV was found in $35 \%$ of the areas surveyed. WMV-2 was detected in only eight agricultural regions $(23 \%)$.

The incidence of these viruses on different species of Cucurbitaceae surveyed showed that PRSV-W was the most prevalent virus found in almost all species, followed by ZYMV, ZLCV, CMV, and WMV-2 (Table 2). An exception was found for $L$. acutangula, where ZYMV was predominant. This species is usually found as very small isolated plantings throughout the state. Chayote, on the other hand, is a popular crop grown in almost all agricultural regions, being frequently found near other cultivated cucurbit species. In spite of the large number of chayote plantings visited, only five plants from three agricultural regions (3, Araraquara; 9, Bragança Paulista; and 10, Campinas) were found showing viruslike symptoms and gave positive reactions with PRSV-W and ZLCV antisera. All other 18 samples showing symptoms suspected to be caused by virus infection tested negative on PTA-ELISA. As several chayote plantings were located near cucurbit crops from which collected samples tested positive for at least one virus, it is suggested that the low incidence of symptomatic chayote plants associated with virus infection might be due to field resistance present in this species.

Among the wild species, Cayaponia tibiricae, which was previously reported as a natural host for ZYMV (34), was also found infected by PRSV-W and ZLCV. $M$. charantia is another wild species widespread in the state, but despite exhaustive attempts, no plants were found exhibiting viruslike symptoms. Nevertheless, seven symptomless samples of this species were analyzed and were negative for all five viruses tested. Additional studies are underway to determine whether or not $M$. charantia is resistant to infection with these viruses. One asymptomatic sample of Sicyos polyacanthus and one of Trichosanthes cucumerina var. anguina, which are wild species, also tested negative for all five viruses.

Double virus infection was detected in 97 of all samples that tested positive by PTA-ELISA. Among double infected plants, 55\% were infected with PRSV-W and ZYMV, the most frequently detected viruses in the samples. Double infection with PRSV-W + ZLCV and PRSV-W + CMV accounted for 15 and $16 \%$, respectively. A low percentage of doubly infected plants was reported by Luis-Arteaga et al. (16) for mosaic viruses infecting fieldgrown melon in Spain. Triple infection involving different combinations with all viruses detected in these surveys was found in only 10 samples. Only one sample of $C$. pepo was simultaneously infected with PRSV-W, WMV-2, ZLCV, and ZYMV.

A significant percentage of samples from symptomatic cucurbit plants analyzed did not react with the antisera against any of the five viruses (Table 2). The absence of positive reactions may be due to any other mosaic-causing agents, such as Squash mosaic virus (SqMV) or an as yet unidentified virus present in the state. SqMV was once described infecting cu-

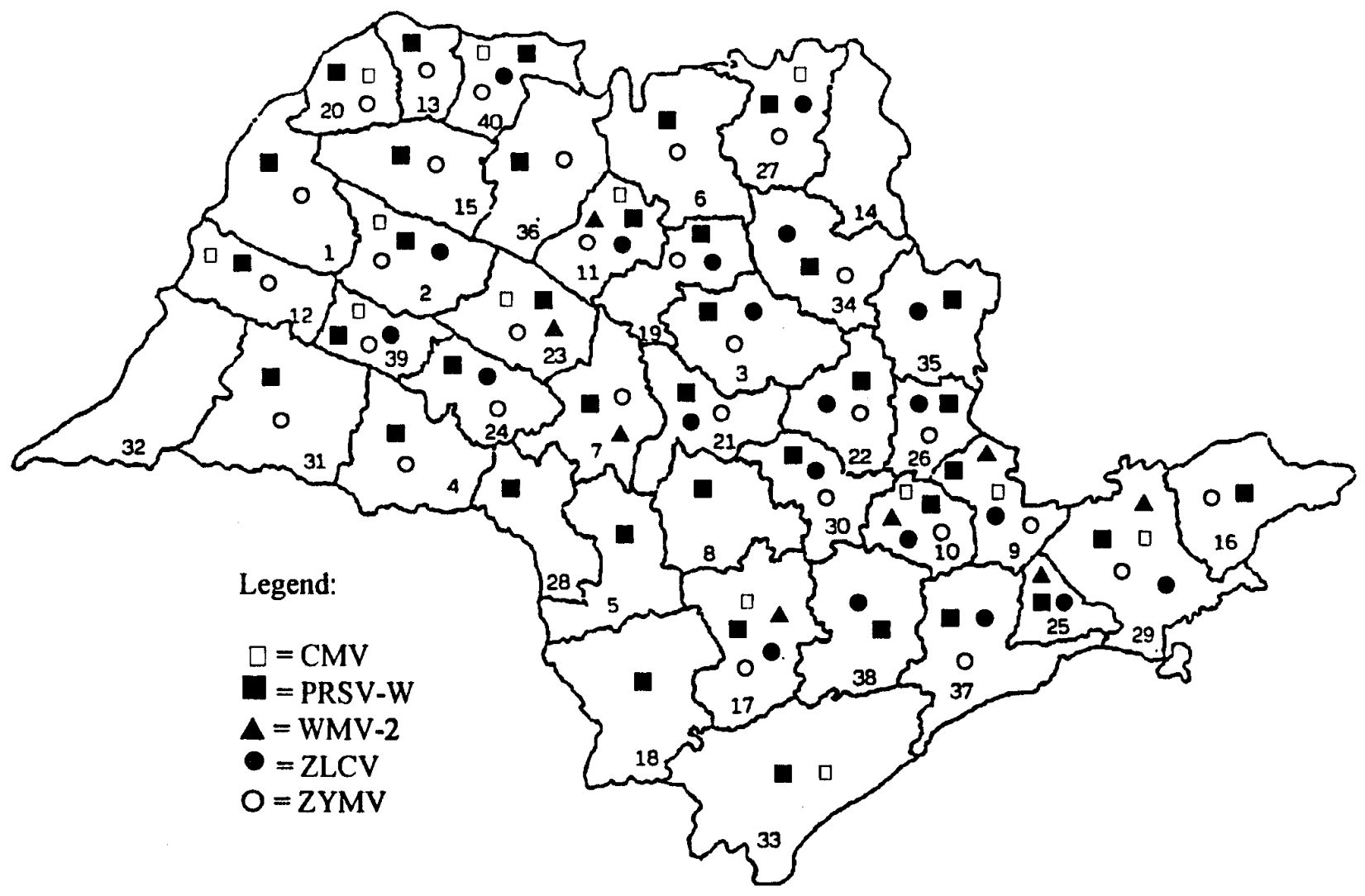

Fig. 1. Map of São Paulo State showing the distribution of five viruses found infecting cucurbit species in 38 of 40 agricultural regions surveyed: 1 , Andradina; 2, Araçatuba; 3, Araraquara; 4, Assis; 5, Avaré; 6, Barretos; 7, Bauru; 8, Botucatu; 9, Bragança Paulista; 10, Campinas; 11, Catanduva; 12, Dracena; 13, Fernandópolis; 14, Franca; 15, General Salgado; 16, Guaratingueta; 17, Itapetininga; 18, Itapeva; 19, Jaboticabal; 20, Jales; 21, Jaú; 22, Limeira; 23, Lins; 24, Marília; 25, Mogi das Cruzes; 26, Mogi Mirim; 27, Orlândia; 28, Ourinhos; 29, Pindamonhangaba; 30, Piracicaba; 31, Presidente Prudente; 32, Presidente Venceslau; 33, Registro; 34, Ribeirão Preto; 35, São João da Boa Vista; 36, São José do Rio Preto; 37, São Paulo; 38, Sorocaba; 39, Tupã; and 40, Votuporanga. 
cumber in São Paulo (4), but antiserum was not available during these surveys. Other factors that might explain negative results on PTA-ELISA are the low concentration of virus in the sample being tested or abiotic agents causing viruslike symptoms, as reported by Yuki et al. (33).
These data show for the first time the identities of viruses infecting commercially grown cucurbits in São Paulo. PRSV-W, considered the most prevalent and destruc-

Table 1. Occurrence of viruses on cucurbit species with viruslike symptoms collected from 38 agricultural regions in São Paulo State, Brazil, during May 1997 and June 1999

\begin{tabular}{|c|c|c|c|c|c|c|}
\hline \multirow[b]{2}{*}{ Region } & \multirow[b]{2}{*}{ Fields surveyed } & \multicolumn{5}{|c|}{ PTA-ELISA ${ }^{\mathrm{a}}$} \\
\hline & & CMV & PRSV-W & ZLCV & ZYMV & WMV-2 \\
\hline Andradina & 4 & $0 / 10^{\mathrm{b}}$ & $1 / 10$ & $0 / 10$ & $3 / 10$ & $0 / 10$ \\
\hline Araçatuba & 9 & $1 / 22$ & $18 / 30$ & $2 / 30$ & $11 / 30$ & $0 / 12$ \\
\hline Araraquara & 5 & $0 / 16$ & $9 / 16$ & $5 / 16$ & $7 / 16$ & $0 / 16$ \\
\hline Assis & 3 & $0 / 5$ & $5 / 5$ & $0 / 5$ & $1 / 5$ & $0 / 5$ \\
\hline Avaré & 3 & $0 / 4$ & $3 / 4$ & $0 / 4$ & $0 / 4$ & $0 / 4$ \\
\hline Barretos & 1 & $0 / 3$ & $1 / 3$ & $0 / 3$ & $1 / 3$ & $0 / 3$ \\
\hline Bauru & 5 & $0 / 10$ & $10 / 10$ & $0 / 10$ & $5 / 10$ & $3 / 10$ \\
\hline Botucatu & 2 & $0 / 2$ & $2 / 2$ & $0 / 2$ & $0 / 2$ & $0 / 2$ \\
\hline Bragança Paulista & 10 & $3 / 44$ & $18 / 48$ & $6 / 48$ & $5 / 48$ & $2 / 43$ \\
\hline Campinas & 10 & $1 / 32$ & $22 / 53$ & $4 / 65$ & $13 / 53$ & $2 / 42$ \\
\hline Catanduva & 7 & $3 / 10$ & $6 / 10$ & $1 / 10$ & $4 / 10$ & $2 / 10$ \\
\hline Dracena & 2 & $1 / 10$ & $7 / 10$ & $0 / 10$ & $6 / 10$ & NT \\
\hline Fernandópolis & 6 & $0 / 11$ & $3 / 12$ & $0 / 12$ & $1 / 12$ & $0 / 1$ \\
\hline General Salgado & 1 & NT & $1 / 5$ & NT & $4 / 5$ & $0 / 5$ \\
\hline Guaratingueta & 5 & $0 / 11$ & $7 / 11$ & $0 / 11$ & $1 / 11$ & $0 / 11$ \\
\hline Itapetininga & 6 & $2 / 12$ & $6 / 12$ & $1 / 12$ & $2 / 12$ & $1 / 12$ \\
\hline Itapeva & 1 & $0 / 12$ & $7 / 12$ & $0 / 12$ & $0 / 12$ & $0 / 12$ \\
\hline Jaboticabal & 9 & $0 / 23$ & $20 / 29$ & $2 / 29$ & $10 / 29$ & $0 / 23$ \\
\hline Jales & 7 & $4 / 25$ & $8 / 25$ & $0 / 25$ & $1 / 25$ & NT \\
\hline Jaú & 7 & $0 / 10$ & $10 / 37$ & $1 / 37$ & $8 / 37$ & $0 / 23$ \\
\hline Limeira & 6 & $0 / 10$ & $1 / 12$ & $3 / 12$ & $5 / 12$ & $0 / 10$ \\
\hline Lins & 13 & $3 / 41$ & $11 / 41$ & $0 / 41$ & $6 / 41$ & $1 / 35$ \\
\hline Marília & 3 & $0 / 10$ & $9 / 10$ & $1 / 10$ & $1 / 10$ & $0 / 10$ \\
\hline Mogi das Cruzes & 5 & $0 / 6$ & $5 / 8$ & $2 / 8$ & $0 / 8$ & $1 / 8$ \\
\hline Mogi Mirim & 7 & $0 / 14$ & $3 / 14$ & $4 / 14$ & $2 / 14$ & $0 / 14$ \\
\hline Orlândia & 1 & $1 / 8$ & $10 / 12$ & $2 / 12$ & $5 / 12$ & NT \\
\hline Ourinhos & 9 & $0 / 10$ & $8 / 10$ & $0 / 10$ & $2 / 10$ & $0 / 10$ \\
\hline Pindamonhangaba & 5 & $3 / 15$ & $9 / 15$ & $1 / 15$ & $4 / 15$ & $7 / 15$ \\
\hline Piracicaba & 7 & $0 / 7$ & $9 / 20$ & $4 / 20$ & $2 / 20$ & $0 / 20$ \\
\hline Presidente Prudente & 2 & $0 / 2$ & $1 / 2$ & $0 / 2$ & $1 / 2$ & $0 / 2$ \\
\hline Registro & 9 & $6 / 19$ & $12 / 27$ & $0 / 27$ & $0 / 27$ & $0 / 19$ \\
\hline Ribeirão Preto & 10 & $0 / 14$ & $8 / 14$ & $1 / 14$ & $6 / 14$ & $0 / 1$ \\
\hline São João da Boa Vista & 6 & $0 / 7$ & $5 / 7$ & $2 / 7$ & $0 / 7$ & $0 / 7$ \\
\hline São José do Rio Preto & 8 & $0 / 8$ & $10 / 12$ & $0 / 12$ & $6 / 12$ & $0 / 10$ \\
\hline São Paulo & 4 & $0 / 10$ & $5 / 10$ & $1 / 10$ & $1 / 10$ & $0 / 10$ \\
\hline Sorocaba & 6 & $0 / 10$ & $9 / 10$ & $3 / 10$ & $0 / 10$ & $0 / 7$ \\
\hline Tupã & 10 & $1 / 33$ & $11 / 33$ & $1 / 33$ & $23 / 33$ & $0 / 7$ \\
\hline Votuporanga & 5 & $1 / 10$ & $2 / 13$ & $1 / 13$ & $3 / 13$ & $0 / 3$ \\
\hline Total & 219 & $30 / 506$ & $297 / 614$ & $48 / 621$ & $150 / 614$ & $19 / 432$ \\
\hline
\end{tabular}

${ }^{a}$ Plate trapped antigen enzyme-linked immunosorbent assay. Cucumber mosaic virus (CMV), Papaya ringspot virus-type W (PRSV-W), Zucchini lethal chlorosis virus (ZLCV), Zucchini yellow mosaic virus (ZYMV), and Watermelon mosaic virus-2 (WMV-2).

${ }^{\mathrm{b}}$ Number of infected plants/number of plants sampled.

Table 2. Occurrence of viruses on cucurbit species with viruslike symptoms collected from fields in São Paulo State, Brazil, during May 1997 and June 1999

\begin{tabular}{|c|c|c|c|c|c|c|c|}
\hline \multirow[b]{2}{*}{ Species } & \multicolumn{5}{|c|}{ PTA-ELISA $^{\mathrm{a}}$} & \multirow{2}{*}{$\begin{array}{c}\text { Double } \\
\text { infection }\end{array}$} & \multirow{2}{*}{$\begin{array}{c}\text { Triple } \\
\text { infection }\end{array}$} \\
\hline & CMV & PRSV-W & ZLCV & ZYMV & WMV-2 & & \\
\hline Cucurbita moschata & $2 / 182^{b}$ & $116 / 226$ & $19 / 217$ & $55 / 226$ & $4 / 176$ & 37 & 3 \\
\hline C. maxima & $0 / 13$ & $8 / 14$ & $0 / 14$ & $2 / 14$ & $0 / 9$ & 0 & 0 \\
\hline C. moschata $\times$ C. maxima & $0 / 23$ & $11 / 24$ & $2 / 24$ & $5 / 24$ & $0 / 3$ & 6 & 0 \\
\hline C. реро & $0 / 58$ & $54 / 78$ & $11 / 88$ & $16 / 78$ & $9 / 59$ & 16 & 5 \\
\hline Cucumis anguria & $3 / 12$ & $11 / 12$ & $1 / 12$ & $0 / 12$ & $0 / 10$ & 3 & 0 \\
\hline C. melo & $5 / 26$ & $13 / 26$ & $0 / 26$ & $11 / 26$ & $0 / 11$ & 4 & 0 \\
\hline C. sativus & $14 / 109$ & $46 / 138$ & $12 / 144$ & $40 / 138$ & $5 / 96$ & 19 & 2 \\
\hline Citrullus lanatus & $1 / 24$ & $22 / 32$ & $1 / 32$ & $6 / 32$ & $1 / 15$ & 6 & 0 \\
\hline Luffa acutangula & $1 / 14$ & $3 / 14$ & $0 / 14$ & $11 / 14$ & $0 / 10$ & 1 & 0 \\
\hline Sechium edule & $0 / 22$ & $4 / 23$ & $1 / 23$ & $0 / 23$ & $0 / 21$ & 0 & 0 \\
\hline Lagenaria siceraria & $4 / 11$ & $8 / 11$ & $0 / 11$ & $2 / 11$ & $0 / 10$ & 4 & 0 \\
\hline Cayaponia tibiricae & $0 / 3$ & $1 / 7$ & $1 / 7$ & $2 / 7$ & $0 / 3$ & 1 & 0 \\
\hline Total & $30 / 497$ & $297 / 605$ & $48 / 612$ & $150 / 605$ & $19 / 423$ & 97 & 10 \\
\hline$\%$ infected & 6.0 & 49.1 & 7.8 & 24.8 & 4.5 & & \\
\hline
\end{tabular}

${ }^{a}$ Plate trapped antigen enzyme-linked immunosorbent assay. Cucumber mosaic virus (CMV), Papaya ringspot virus-type W (PRSV-W), Zucchini lethal chlorosis virus (ZLCV), Zucchini yellow mosaic virus (ZYMV), and Watermelon mosaic virus-2 (WMV-2).

${ }^{\mathrm{b}}$ Number of plants positive/number of plants sampled. 
tive virus in several parts of the country, including São Paulo, was confirmed to be the most frequent virus detected. ZYMV was not detected in the state until early 1990. It was first reported in São Paulo in 1992, infecting a few watermelon plants in the agricultural region of Votuporanga, no. 40 (32). Since then, this virus has quickly spread and become the second in incidence, being found in $82 \%$ of the regions surveyed throughout the state. It has also been reported infecting cucumber in the state of Santa Catarina (3), melon in the state of Ceará (13), and L. acutangula in the state of Bahia (21). More recently, it was detected in watermelon samples from the state of Pará (L. S. Poltronieri, unpublished), suggesting that ZYMV is already established throughout the country. ZYMV is considered aggressive and highly virulent. Due to its aphid transmission properties, the virus may have important epidemiological advantages. When inoculations were done from mixed infections with PRSV-W or WMV-2, more often ZYMV was transmitted (11). If this happens from plants with double infection, it could provide an advantage to ZYMV and contribute to its rapid spread.

The occurrence of a tospovirus infecting cucurbit species in Brazil was first noticed by Costa et al. (5) on $C$. sativus in São Paulo, but for several years it was not considered a major problem in Cucurbitaceae. Since the early 1990s, however, an increased incidence of ZLCV infection on cucurbits has occurred. ZLCV is transmitted by Frankliniella zucchini (19), but other species of thrips may also be vectors of this virus. The susceptibility of several cucurbit species to ZLCV, as shown in this survey, and the presence of several species of thrips may provide conditions for further increase in the incidence of this tospovirus on Cucurbitaceae. On the other hand, the low incidence of WMV-2, which was first reported in São Paulo in 1985 in the Campinas agricultural region, no. 10 (28), and which is the most prevalent virus in the northeast states of Bahia and Pernambuco (6), is puzzling. Even though WMV-2 is transmitted in a nonpersistant way by several species of aphids (23), its dissemination throughout São Paulo appears to be restricted for some unknown reason. Studies on aphid transmission and alternative hosts of WMV-2 could help us understand its lower incidence in São Paulo.

Although PRSV-W is the most prevalent virus affecting cucurbits in the state of São Paulo, its relatively high incidence cannot be considered a stable pattern, as has been shown for cucurbit viruses in the United States. Studies in California conducted from the 1950s through 1981 indicated that WMV-2 and CMV were the most prevalent viruses $(9,17,20)$. In 1982, ZYMV was identified for the first time in that state (20). Surveys of melon fields from the
Central Valley of California during 1988 and 1989 showed that WMV-2 was the most prevalent virus, followed by CMV and ZYMV (8). In the southernmost region of California, WMV-2 and ZYMV were the predominant viruses (23). Recent studies showed that WMV (possibly WMV-2), CMV, and Cucurbit aphid-borne yellow luteovirus were the three viruses detected in Cucurbitaceae in the San Joaquin and Sacramento valleys of California (31).

The same has also been observed for cucurbit viruses in some Hawaiian Islands. Shanmugasundaram et al. (29) reported that in the 1960s, PRSV-W, WMV-2, and CMV were the most common viruses. In 1991, ZYMV and PRSV-W were the most prevalent in cucurbit crops, whereas CMV was seldom found and WMV-2 was no longer detected (30).

Surveys of melon during 1995 and 1996 showed that CMV and WMV-2 were the most frequently found viruses in Spain, whereas PRSV-W and ZYMV were detected at fewer sites in lower incidences. PRSV-W accounted for only $9 \%$ of total virus-infected plants in 1995 and was not detected in 1996 (16).

The presence of cultivated and wild cucurbit species in São Paulo throughout the year, plus favorable weather for vector populations, make virus diseases one of the most important problems for growers. Therefore, a better understanding of virus and vector reservoirs, vector population behavior, and vector transmission efficiency are necessary for the development of effective control measurements. The most important strategy for control of virus diseases on cucurbits in São Paulo would be the elimination of the common practice of starting new crops near old infected plantings. Old crops should be destroyed before starting new plantings. Control of wild species of Cucurbitaceae in the vicinity of cucurbit crops would reduce virus sources. Control of weeds that harbor vectors is also recommended. Use of resistant or tolerant cultivars and/or mild strain protection should be practiced whenever available. Mild strain protection has been successfully applied for control of PRSVW on zucchini squash in São Paulo since 1997 (26). Use of tolerant C. moschata cv. Menina Brasileira in combination with mild strains of PRSV-W has also provided better disease control, with approximately $30 \%$ yield increase $(27)$.

\section{ACKNOWLEDGMENTS}

This research was supported by grants from FAPESP (Fundação do Amparo à Pesquisa do Estado de São Paulo, Brazil), Proc. 96/6739-0 and Pronex (41.96.0898.00). We thank extension agronomists from the agricultural regions (CATI) for help with cucurbit samplings and J. E. Buriolla for technical assistance with ELISAs.

\section{LITERATURE CITED}

1. Albuquerque, F. C., Ikeda, H., and Costa, A. S. 1972. Ocorrência do vírus do mosaico da melancia (Citrullus vulgaris Schrad.) em plantações de melão (Cucumis melo L.) na região de Belém-PA. (Abstr.) Rev. Olericult. 12:94.

2. Anuário de Informações Estatísticas da Agricultura. 1999. Instituto de Economia Agrícola, São Paulo, Vol. 10, No. 1.

3. Caner, J., Galleti, S. R., Lotz, I. P. M., and Oliveira, J. M. 1992. Natural infection of cucumber (Cucumis sativus) by zucchini yellow mosaic virus (ZYMV) in Santa Catarina, Brazil. (Abstr.) VI Encontro Nacional de Virologia, São Lourenço, MG. p. 180.

4. Chagas, C. M. 1970. Mosaico da abóbora em pepino. O Biológico 36:326.

5. Costa, A. S., Kitajima, E. W., and Nagai, H. 1972. Alguns vírus que afetam o pepino (Cucumis sativus L.) em São Paulo. (Abstr.) Rev. Olericult. 12:100-101.

6. Cruz, E. S., Paz, C. D., Pio-Ribeiro, G., Batista, D. C., Pereira Filho, G. G., and Andrade G. P. 1999. Levantamento de viroses em melancia e melão no submédio São Francisco. Summa Phytopathol. 25:21

7. Cupertino, F. P., Costa, C. L., Kitajima, E. W., Mattos, J. K. A., and Araujo, M. T. 1974 Vírus de cucurbitáceas no D. Federal. (Abstr.) Fitopatologia 9:51.

8. Grafton-Cardwell, E. E., Perring, T. M., Smith, R. F., Valencia, J., and Farrar, C. A. 1996. Occurrence of mosaic viruses in melons in the Central Valley of California. Plant Dis. 80:1092-1097.

9. Grogan, R. G., Hall, D. H., and Kimble, K. A. 1959. Cucurbit mosaic viruses in California Phytopathology 49:366-376.

10. Kitajima, E. W., Sá, P. B., Ritzinger, C. H. S. P., and Rodrigues, M. G. R. 1991. Detecção de partículas do tipo rhabdovirus em algumas compostas, aboboreira e mamoeiro. Fitopatol. Bras. 16:141-144.

11. Lecoq, H., and Pitrat, M. 1985. Specificity of the helper-component-mediated aphid transmission of three potyviruses infecting muskmelon. Phytopathology 75:890-893.

12. Lima, J. A. A., Fernandes, E. R., and Mendes, M. L. 1980. Identificação sorológica de "watermelon mosaic virus 1" em cucurbitáceas cultivadas e nativas do Rio Grande do Norte. (Abstr.) Fitopatol. Bras. 5:414.

13. Lima, J. A. A., Oliveira, V. B., and Vale, C. C. 1996. Purification and serology of zucchini yellow mosaic virus isolated from Cucumis melo 'AF-522'. (Abstr.) VIII Encontro Nacional de Virologia, São Lourenço, MG. p. 278.

14. Lima J. A. A., and Vieira, A. C. 1992. Distribuição do vírus do mosaico da abóbora em municípios cearences e gama de hospedeiros de um isolado. Fitopatol. Bras. 17:112-114.

15. Lin, M. T., Kitajima, E. W., and Munhoz, J O. 1983. Isolamento e propriedade do vírus da necrose da abóbora, um possível membro do grupo "Tobacco Necrosis Virus". (Abstr.) Fitopatol. Bras. 8:622.

16. Luis-Arteaga, M., Alvarez, J. M., AlonsoPrados, J. L., Bernal, J. J., García-Arenal, F., Laviña, A., Batlle, A., and Moriones, E. 1998. Occurrence, distribution, and relative incidence of mosaic viruses infecting field-grown melon in Spain. Plant Dis. 82:979-982.

17. Milne, K. S., Grogan, R. G., and Kimble, K A. 1969. Identification of viruses infecting Cucurbits in California. Phytopathology 59:819-828.

18. Mowat, W. P., and Dawson, S. 1987. Detection of plant viruses by ELISA using crude sap extracts and unfractionated antisera. J. Virol. Methods 15:233-247.

19. Nakahara, S., and Monteiro, R. C. 1999 Frankliniella zucchini (Thysanoptera: Thripidae), a new species and vector of Tospovirus 
in Brazil. Proc. Entomol. Soc. Wash. 101:290294.

20. Nameth, S. T., Dodds, J. A., Paulus, A. O., and Laemmlen, F. F. 1986. Cucurbit viruses of California: An ever-changing problem. Plant Dis. 70:8-12.

21. Novaes, Q. S., Rezende, J. A. M., and Kitajima, E. W. 1999. Ocorrência dos vírus do mosaico amarelo e da clorose letal em cucurbitáceas no Estado da Bahia. (Abstr.) Summa Phytopathol. 25:37.

22. Pavan, M. A., Carvalho, M. G., and Fernandes, J. J. 1989. Distribuição do vírus do mosaico da melancia (papaya ringspot virus W), nas principais regiões produtoras de pepino (Cucumis sativus) e abobrinha (Cucurbita pepo) de Minas Gerais. Fitopatol. Bras. 14:84-85.

23. Perring, T. M., Farrar, C. A., Mayberry, K., and Blua, M. J. 1992. Research reveals pattern of cucurbit virus spread. Calif. Agric. 46:35-40.

24. Pozzer, L., Nagata, T., Lima, M. I., Kitajima, E. W., Resende, R. O., and De Ávila, A. C. 1994. A new tospovirus infecting Cucurbitaceae in Brazil. (Abstr.) Fitopatol. Bras. 19:21.
25. Pozzer, L., Resende, R. O., Bezerra, M. I., Nagata, T., Lima, M. I., Kitajima, E. W., and Ávila, A. C. 1996. Zucchini lethal chlorotic virus (ZLCV), a proposed new species in the Tospovirus genus. (Abstr.) Fitopatol. Bras. 21(suppl.):432.

26. Rezende, J. A. M., and Pacheco, D. A. 1998. Control of papaya ringspot virus-type $\mathrm{W}$ in zucchini squash by cross protection in Brazil. Plant Dis. 82:171-175.

27. Rezende, J. A. M., Pacheco, D. A., and Iemma, A. F. 1999. Efeitos da preimunização da abóbora 'Menina Brasileira' com estirpes fracas do vírus do mosaico do mamoeiro estirpe melancia. Pesq. Agropec. Bras. 34:1481-1489.

28. Sá, P. B. de, and Kitajima, E. W. 1991. Characterization of an isolate of watermelon mosaic virus 2 (WMV-2) from Brazil. Fitopatol. Bras. 16:217-233.

29. Shanmugasundaram, S., Ishii, M., Gilbert, J. C., and Nagai, H. 1969. Cucurbit virus studies in Hawaii. Plant Dis. Rep. 53:70-74.

30. Ullman, D. E., Cho, J. J., and German, T. L. 1991. Occurrence and distribution of cucurbit viruses in the Hawaiian islands. Plant Dis.
75:367-370.

31. Umesh, K. C., Valencia, J., Gubler, W. D., and Falk, B. W. 1995. The incidence of aphids and aphid-transmitted viruses in melon cultivars and breeding lines in California. (Abstr.) Phytopathology 85:1042.

32. Vega, J., Rezende, J. A. M., and Yuki, V. A. 1995. Detecção do vírus do mosaico amarelo da abobrinha de moita no Brasil: Caracterização parcial de um isolado encontrado em São Paulo. Fitopatol. Bras. 20:72-79.

33. Yuki, V. A., Kuniyuki, H., Groppo, G. A. Rezende, J. A. M., Kitajima, E. W., and Pavan, M. A. 1999. Anomalias de natureza diversa observadas em cucurbitáceas cultivadas em São Paulo. (Abstr.) Summa Phytopathol. 25:51.

34. Yuki, V. A., Rezende, J. A. M., Kitajima, E. W., Barroso, P. A. V., Kuniyuki, H., Groppo, G. A., and Pavan, M. A. 1999. Cayaponia tibiricae: New host of zucchini yellow mosaic virus in Brazil. Plant Dis. 83:486.

35. Zitter, T. A., Hopkins, D. L., and Thomas, C. E. 1996. Compendium of Cucurbit Diseases. American Phytopathological Society, St. Paul, MN. 